Article

\title{
From Plant to Paddy-How Rice Root Iron Plaque Can Affect the Paddy Field Iron Cycling
}

\author{
Markus Maisch ${ }^{1}{ }^{\oplus}$, Ulf Lueder ${ }^{1}$, Andreas Kappler ${ }^{1,2}$ and Caroline Schmidt ${ }^{1, *}$ \\ 1 Geomicrobiology, Center for Applied Geoscience, University of Tuebingen, 72074 Tuebingen, Germany; \\ markus.maisch@uni-tuebingen.de (M.M.); ulf.lueder@uni-tuebingen.de (U.L.); \\ andreas.kappler@uni-tuebingen.de (A.K.) \\ 2 Center for Geomicrobiology, Department of Bioscience, University of Aarhus, 8000 Aarhus, Denmark \\ * Correspondence: caroline.schmidt@uni-tuebingen.de; Tel.: +49-7071-29-70880
}

Received: 27 March 2020; Accepted: 28 April 2020; Published: 30 April 2020

\begin{abstract}
Iron plaque on rice roots represents a sink and source of iron in paddy fields. However, the extent of iron plaque in impacting paddy field iron cycling is not yet fully deciphered. Here, we followed iron plaque formation during plant growth in laboratory-controlled setups containing a transparent soil matrix. Using image analysis, microsensor measurements, and mineral extractions, we demonstrate that radial oxygen loss (ROL) is the main driver for rhizosphere iron oxidation. While $\mathrm{O}_{2}$ was restricted to the vicinity of roots, root tips showed highest spatio-temporal variation in $\mathrm{ROL}(<5-50 \mu \mathrm{M})$ following diurnal patterns. Iron plaque covered $>30 \%$ of the total root surface corresponding to $60-180 \mathrm{mg} \mathrm{Fe}(\mathrm{III})$ per gram dried root and gradually transformed from low-crystalline minerals (e.g., ferrihydrite) on root tips, to $>20 \%$ higher-crystalline minerals (e.g., goethite) within 40 days. Iron plaque exposed to an Fe(III)-reducing Geobacter spp. culture resulted in 30\% $\mathrm{Fe}$ (II) remobilization and $>50 \%$ microbial transformation to Fe(II) minerals (e.g., siderite, vivianite, and Fe-S phases) or persisted by $>15 \%$ as Fe(III) minerals. Based on the collected data, we estimated that iron plaque formation and reductive dissolution can impact more than $5 \%$ of the rhizosphere iron budget which has consequences for the (im)mobilization of soil contaminants and nutrients.
\end{abstract}

Keywords: paddy fields; iron plaque; microaerophilic Fe(II) oxidation; Fe(III) reduction; contaminant (im)mobilization

\section{Introduction}

Paddy fields cover more than $6 \%$ of arable land surface and represent the basis for cultivation of rice, the major food crop for more than half of the world's population. Most commonly, rice plants are cultivated on flooded paddy fields. Under these water-logged conditions, the submerged soil is typically depleted in oxygen $\left(\mathrm{O}_{2}\right)$ and rich in organics-an ideal habitat for Fe(III)-reducing microorganisms [1]. Using Fe(III) minerals as terminal electron acceptor, these bacteria significantly impact the redox state of soil-borne iron minerals and fuel the pool of dissolved Fe(II $)_{\text {aq }}$ in the pore water by remobilizing $\mathrm{Fe}(\mathrm{II})_{\mathrm{aq}}$ from minerals through reductive dissolution. This typically leads to high concentrations of more than a few hundred micromoles of dissolved and phytoavailable Fe(II) in the rhizosphere pore water of paddy fields [2].

Iron is an essential trace element for photosynthesis [3,4]. However, high concentrations of phytoavailable $\mathrm{Fe}$ (II) ultimately lead to an intoxication of the photosystem and leaf bronzing in rice plants [5]. In order to control the uptake of $\mathrm{Fe}(\mathrm{II})_{\mathrm{aq}}$, rice plants release $\mathrm{O}_{2}$ from roots by so-called radial oxygen loss (ROL) [6]. At circumneutral $\mathrm{pH}, \mathrm{Fe}$ (II) gets rapidly chemically oxidized by $\mathrm{O}_{2}$ from $\mathrm{ROL}$ to ferric iron ( $\mathrm{Fe}(\mathrm{III})$ ) and precipitates as $\mathrm{Fe}(\mathrm{III})$ (oxyhydr)oxides on and around the root surface as iron plaque [7]. These Fe(III) (oxyhydr)oxides represent a highly reactive mineral fraction in the soil 
horizons as they not only participate in the immobilization of essential plant nutrients but impact, to a large extent, the sequestration of many other soil components such as contaminants and trace elements [6,8-11].

It is hypothesized that an enormous variety of microorganisms is involved in iron cycling in the rhizosphere and that they considerably affect the iron redox cycle in water-logged paddy soils [12]. However, it was shown for only a few examples that iron-metabolizing bacteria can find ideal conditions in the paddy field rhizosphere $[13,14]$. Examples include microaerophilic $\mathrm{Fe}(\mathrm{II})$-oxidizing bacteria which were shown to kinetically contribute to Fe(II) oxidation under microoxic conditions $[15,16]$. Furthermore, Emerson et al. [17] provided first evidence that neutrophilic microaerophilic Fe(II)-oxidizing bacteria were often closely associated with roots and root iron plaques in the wetland rhizosphere. Neubauer et al. (2007) [18] demonstrated the potential of these bacteria to enhance iron plaque formation on wetland plant roots and in a recent study the effective habitable zone for microaerophilic $\mathrm{Fe}(\mathrm{II})$-oxidizing bacteria was shown to expand to a large extent throughout the entire rhizosphere during plant growth [19]. Congruent with these findings, it is undoubtable that rice plant roots and microaerophilic $\mathrm{Fe}(\mathrm{II})$-oxidizing bacteria in particular play a major role in iron mineralization in the rhizosphere of flooded paddy fields.

In addition to the foregoing role of soil-borne iron to serve as an electron donor, the iron plaque minerals can also serve as an electron acceptor for Fe(III)-reducing bacteria [20,21]. Reduction of iron plaque minerals not only considerably change the sorption capacities of these iron minerals but leads to a re-mobilization of surface-bound contaminants by microbial reductive dissolution [22,23]. Over the last few decades, research interest towards an understanding of root iron plaque formation, retention of contaminants, and the role of bacteria in re-mobilization have slightly increased [24-28]. Investigations on the microbial community level, determining Fe(II) oxidation and Fe(III) reduction rates, partly complemented the knowledge about a dynamic rhizosphere systems in paddy fields on a large scale [29]. Moreover, famous studies proposed the existence of an active rhizosphere iron cycle promoted by the presence of wetland vegetation such as rice plants in paddy fields [30,31]. However, the extent to which $\mathrm{Fe}(\mathrm{II})$-oxidizing and Fe(III)-reducing bacteria might be involved in this redox-active iron cycling around the roots has not been investigated so far.

In the current study, we aim to demonstrate that rice plant roots not only span up a biogeochemical network that creates a narrowly closed iron cycle in the entire rice plant rhizosphere but actively contribute to the cycle by iron mineral (trans)formation. Furthermore, we intended (i) to quantify the ROL-induced iron plaque mineral formation; (ii) to analyze the potential spatio-dynamic impact of microaerophilic Fe(II) oxidation, and (iii) to determine the capability of microbial Fe(III) reduction for iron plaque dissolution and Fe remobilization. By implementing experimental data from laboratory-controlled incubation and rhizotron studies, we were able to estimate the plant and microbially induced budget for $\mathrm{Fe}(\mathrm{II})$ oxidation, while the derivation of rates for Fe(III) reduction are closing the rhizosphere iron cycle on the reductive side. These findings advance the understanding of complex rhizosphere iron redox interactions and help to quantify iron fluxes between dominant iron-reducing and -oxidizing processes in a rice plant rhizosphere during rice plant growth.

\section{Materials and Methods}

\subsection{Plant Cultivation}

Rice seeds (Oryza sativa Nipponbare) were sterilized $\left(0.1 \% \mathrm{H}_{2} \mathrm{O}_{2}\right.$ rinse, ultrapure water) and seedlings were pre-grown in sterile 50\% Hoagland [32] solution at $\mathrm{pH}$ 6.8. For rhizotron studies in the growth gel, seedlings were transferred into anoxic and sterile rhizotrons (described in Maisch et al., 2019a and Supporting Information) and consecutively covered with opaque fabric to prevent illumination of the roots. For hydroponic cultivation, pre-grown seedlings were transferred at three-leaf stage into anoxic hydroponic setups with $500 \mathrm{~mL}$ of $100 \%$ Hoagland solution amended with $500 \mu \mathrm{M}$ $\mathrm{Fe}(\mathrm{II})_{\mathrm{aq}}$, buffered (PIPES, $20 \mathrm{mM}$ ) at $\mathrm{pH}$ 6.8. Setups were wrapped in aluminum foil in order to prevent 
illumination of the growth solution and the roots. Decline in hydroponic medium by evapotranspiration was replaced by anoxic and sterile $50 \%$ Hoagland solution at $\mathrm{pH} 6.8$ and $500 \mu \mathrm{M} \mathrm{Fe}(\mathrm{II})_{\mathrm{aq}}$. Plants were kept at temperature-controlled conditions $\left(25-27^{\circ} \mathrm{C}, 70 \%\right.$ rel. humidity) following day (14 h)-night $(10 \mathrm{~h})$ cycles illuminated by a high-pressure sodium lamp (10,000-12,000 lx).

\subsection{Geochemical Measurements and Image Analysis in Rhizotrons}

Using planar optode sensor foils, $\mathrm{O}_{2}$ and $\mathrm{pH}$ were measured non-invasively from outside the rhizotrons as described in Maisch et al. (2019a). For the quantification of averaged local $\mathrm{O}_{2}$ concentrations, designated regions of interests (ROI) with dimensions of $10 \times 10 \mathrm{~mm}\left(1 \mathrm{~cm}^{2}\right)$ were defined in recorded images at different time points using the software VisiSens ScientifiCal ${ }^{\odot}$ (Presens, Regensburg, Germany). In-situ Fe(II) aq concentrations were spatially quantified by Voltammetry (Cu-Au sensors with a Hg-Au alloy surface $(100 \mu \mathrm{m})$, hooked to a potentiostat (DLK-70, Analytical Instrument Systems, Flemington, NJ, US)). Homogeneous $\mathrm{Fe}(\mathrm{II})$ oxidation rates were calculated based on geochemical parameters in the rhizotrons following the method described in [16,33]. Images of the root-zone were recorded following the simulated daylight period with a digital camera (EOS 1200D, Canon) using constant camera settings. Image analysis and quantification of oxidized areas in the rhizosphere were performed on the basis of pixel identity and color thresholding [34-36] as also described in Maisch et al. (2019a). On that basis, particle analysis was performed to quantify the area of iron plaque on root surfaces at individual time intervals. The surface of root iron plaque minerals was estimated by extrapolating the two-dimensional area of iron plaque formation $\left(\mathrm{A}_{\text {image }}\right)$

$$
\mathrm{A}_{\text {image }}=2 \times \mathrm{r} \times \mathrm{h}=\mathrm{d} \times \mathrm{h}
$$

with $\mathrm{h}(\mathrm{cm})$ as imaging area height, $\mathrm{r}(\mathrm{cm})$ as imaging area radius and $\mathrm{d}(\mathrm{cm})$ as imaging area diameter to a three-dimensional outer surface mantle area of ideal cylindrical roots [37] as an approximation for the mineral surface of root iron plaque $\left(\mathrm{A}_{\text {iron plaque }}\right)$

$$
\mathrm{A}_{\text {iron plaque }}=2 \times \mathrm{r} \times \pi \times \mathrm{h}
$$

summarized in the following simplified equation as

$$
\mathrm{A}_{\text {iron plaque }}=\mathrm{A}_{\text {image }} \times \pi
$$

\subsection{Iron Plaque Mineral Identification}

Roots covered in iron plaque minerals were collected 48 days after plant transplantation under anoxic conditions inside a glovebox $\left(100 \% \mathrm{~N}_{2}\right)$ from root tips (young roots), the middle parts of roots (approx. 20 days old roots), and basal root zone (approx. 40 days old roots). Iron minerals were identified using Mössbauer spectroscopy (Supporting Information).

\subsection{Iron Plaque Reduction in Liquid Culture}

After 52 days on hydroponic cultivation, rice plants were removed from Hoagland solution, green biomass was detached and roots were transferred individually into anoxic sterile $500 \mathrm{~mL}$ mineral medium [38] buffered ( $22 \mathrm{mM}$ bicarbonate) at $\mathrm{pH} 6.8$ containing $20 \mathrm{mM}$ Na-acetate as electron donor substrate. A $5 \%(v / v)$ inoculum of an Fe(III)-reducing enrichment culture $(99.8 \%$ identity to Geobacter sp. CD1 [39] based on 16S rRNA) isolated from a paddy field (Vercelli, Italy; Supporting Information) was added to each microcosm. In order to inhibit cell activity in abiotic control incubations, $4 \%$ paraformaldehyde (PFA) were added to the respective setups. Microcosms were kept in the dark at constant temperature $\left(24^{\circ} \mathrm{C}\right)$ for a total of 8 days. 


\subsection{Iron Plaque Reduction in Rhizotrons}

Roots covered in iron plaque were sampled from a 52-day old rice plant which was previously grown on an $\mathrm{Fe}(\mathrm{II})$-rich hydroponic solution. Collected root material was soaked in a cell suspension of an $\mathrm{Fe}(\mathrm{III})$-reducing enrichment culture (see above) and subsequently transferred into a rhizotron that contained warm $\left(35^{\circ} \mathrm{C}\right)$, sterile and anoxic mineral medium [38], amended with $0.3 \%$ Gelrite. After cooling down to room temperature, the mineral medium formed a transparent gel. The rhizotron was kept in the dark at constant temperature $\left(24^{\circ} \mathrm{C}\right)$.

\subsection{Iron Plaque Reduction: Geochemical Measurements and Mineral Identity}

Liquid samples were collected from microcosm setups under anoxic conditions at different time steps. In order to quantify dissolved Fe(II) $)_{a q}$ and particulate $\mathrm{Fe}(\mathrm{II}) /(\mathrm{III})$, filtered $(0.45 \mu \mathrm{m})$ and non-filtered samples were acidified (1:2) in $2 \mathrm{M} \mathrm{HCl}$ to prevent oxidation at ambient atmosphere and were analyzed by the Ferrozine assay [40]. For iron plaque mineral analysis, roots covered in iron plaque were collected randomly prior to the iron plaque reduction experiment and at the end after 10 days from biotic and inhibited control setups. Samples from the rhizotron iron plaque reduction experiment were collected after 10 days and dried under anoxic conditions $\left(28^{\circ} \mathrm{C}, 100 \% \mathrm{~N}_{2}\right)$. Iron minerals in these samples were identified by Mössbauer spectroscopy as described in the Supporting Information. In order to recalculate the total amount of iron plaque on the root prior to microbial reduction, residual iron plaque minerals at the end of the incubation were extracted in $6 \mathrm{M} \mathrm{HCl}$, while dissolved Fe(total) was quantified by the Ferrozine assay. Dissolved, particulate Fe(II)/(III) and extracted Fe(total) were then added up to recalculate a value for the initial total iron plaque on the root surface.

\section{Results}

\subsection{Spatio-Temporal Quantification of $\mathrm{ROL}$ and the Identification of $\mathrm{O}_{2}$ Hot Spots}

Root growth and $\mathrm{O}_{2}$ concentrations were followed in transparent rhizotron setups during plant growth (Figure 1A). After 5 days after transfer (DAT), intermittent $\mathrm{O}_{2}$ was detected in the rhizosphere forming steep gradients ranging from $70 \mu \mathrm{M} \mathrm{O}_{2}$ on the surface of first lateral root tips to $<5 \mu \mathrm{M}$ $\mathrm{O}_{2}$ expanding $6 \mathrm{~mm}$ into the anoxic soil matrix. During root growth, $\mathrm{O}_{2}$ concentrations radially increased in the vicinity of individual roots. On the root surface $\mathrm{O}_{2}$ concentrations reached values of $>100 \mu \mathrm{M}$. Towards the anoxic soil matrix, $\mathrm{O}_{2}$ decreased gradually below the detection limit in a distance of $1.5 \pm 0.5 \mathrm{~cm}$ away from the root surface. While the basal root zone was continuously dominated by oxidized conditions with $\mathrm{O}_{2}$ concentrations $>50 \mu \mathrm{M}$, local oxygenated hot spots with elevated $\mathrm{O}_{2}$ concentrations formed around young root tips. In contrast to the anoxic soil matrix in which $\mathrm{O}_{2}$ was constantly below the detection limit, root tips were continuously surrounded by high $\mathrm{O}_{2}$ concentrations with more than $60 \mu \mathrm{M}$ of $\mathrm{O}_{2}$ at the root tip center. Local $\mathrm{O}_{2}$ concentrations radially expanded around root tips and formed steep $\mathrm{O}_{2}$ gradients that reached 3-15 $\mathrm{mm}$ into the rhizosphere (Figure 1B). This ROL hot spot not only led to an increase in local $\mathrm{O}_{2}$ concentrations but was also found to accelerate chemical Fe(II) oxidation. Abiotic Fe(II) oxidation kinetics were calculated to reach oxidation rates of up to $20 \mu \mathrm{M} \mathrm{Fe}(\mathrm{II})$ hour $^{-1}$ within the radial vicinity of $5 \mathrm{~mm}$ around the root tip center (Figure 1C). 

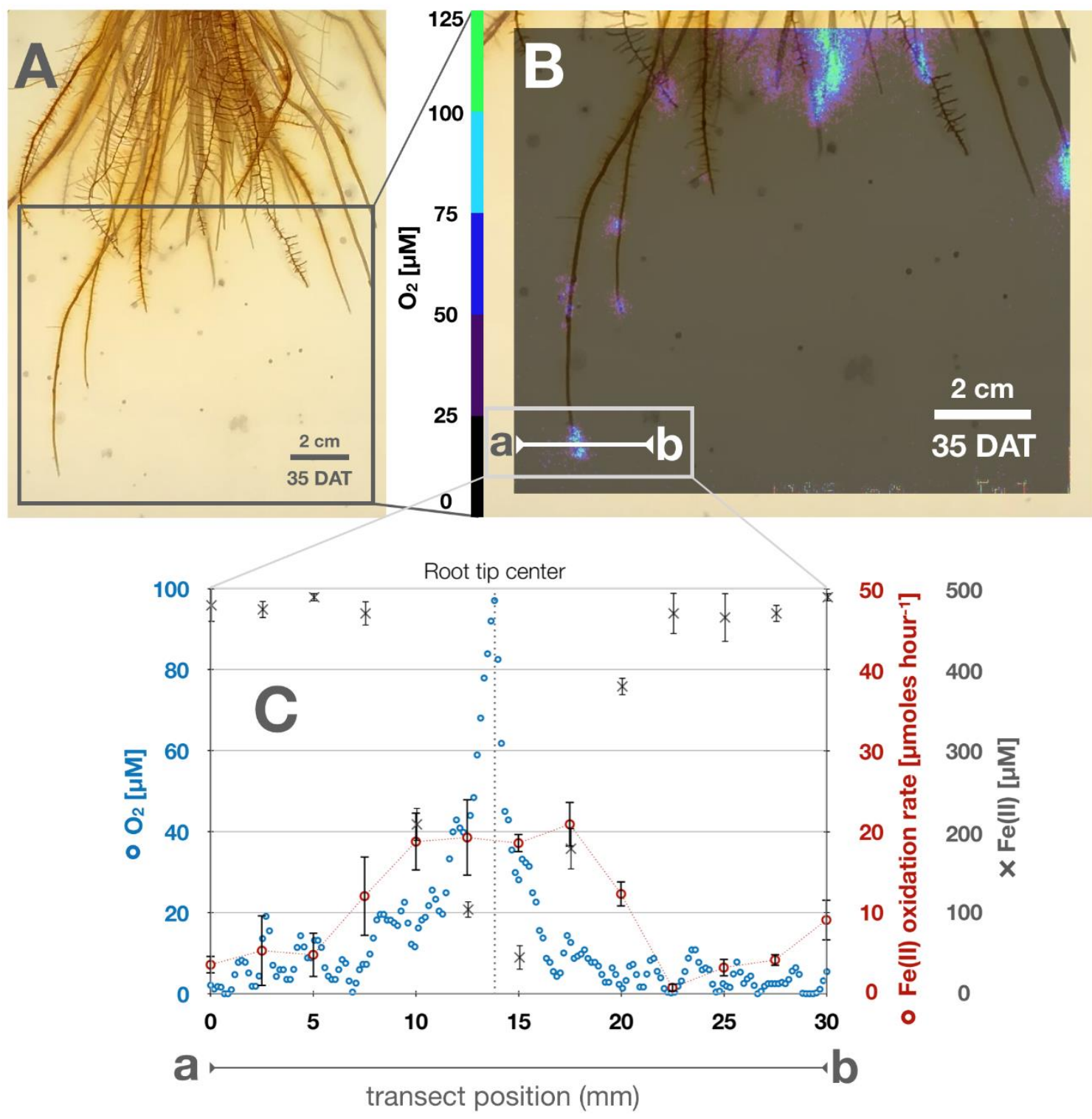

Figure 1. Radial oxygen loss and iron geochemistry at the root-soil interface at the end of light-incubated cycles: (A) Rice roots covered in iron plaque. (B) Radial oxygen concentrations surrounding root tips 35 DAT (DAT = days after transfer), a-b indicates a transect where $\mathrm{O}_{2}$ and $\mathrm{Fe}(\mathrm{II})$ were measured and $\mathrm{Fe}(\mathrm{II})$ oxidation kinetics were calculated. (C) Transect a-b: representative concentrations of $\mathrm{O}_{2}, \mathrm{Fe}$ (II) and calculated homogeneous Fe(II) oxidation rate along transect.

In order to spatio-temporally quantify changes in local $\mathrm{O}_{2}$ patterns surrounding root tips, $\mathrm{O}_{2}$ concentrations were recorded in 5-minute time intervals over a period of $48 \mathrm{~h}$. Local $\mathrm{O}_{2}$ concentrations were quantified in three designated areas $\left(1 \mathrm{~cm}^{2}\right)$ (Figure 2A). Within two diurnal cycles of $24 \mathrm{~h}$ each, highest local $\mathrm{O}_{2}$ concentrations surrounding three designated root tips were observed at the end of light incubated cycles (Figure 2A-D). During dark incubated cycles, local $\mathrm{O}_{2}$ concentrations in the vicinity of root tips remarkably decreased by more than $80 \%$ with $2.7( \pm 1.0) \mu \mathrm{M} \mathrm{hour}^{-1}$ on average within $10 \mathrm{~h}$ of incubation the dark (Figure 2E; Table 1). Examples include $\mathrm{O}_{2}$ hot spots where local $\mathrm{O}_{2}$ concentrations of up to $100 \mu \mathrm{M} \mathrm{O}_{2}$ and a radial expansion of 5-10 $\mathrm{mm}$ in the light decreased to $\mathrm{O}_{2}$ concentrations of $<50 \mu \mathrm{M}$ and a radial expansion of less than $5 \mathrm{~mm}$ in the dark (Figure 1; Figure 2A-D). Repeatedly within $48 \mathrm{~h}$, both the lowest $\mathrm{O}_{2}$ concentrations and lowest degrees in expansion were measured at the end of the dark-incubated cycles among all root tips (Figure 2). With the initiation of illumination, $\mathrm{O}_{2}$ loss from root tips was observed to respond within $2 \mathrm{~h}$ by an increase in local $\mathrm{O}_{2}$ concentrations 
by $2.0( \pm 1.2) \mu \mathrm{M}$ hour $^{-1}$ on average measured at three replicate root tips (Figure 2A-D). Similarly, the radial $\mathrm{O}_{2}$ expansion increased and plateaued between 5-10 $\mathrm{mm}$ after $9 \mathrm{~h}$ of light incubation before it decreased again with the initiation of the following dark cycle.

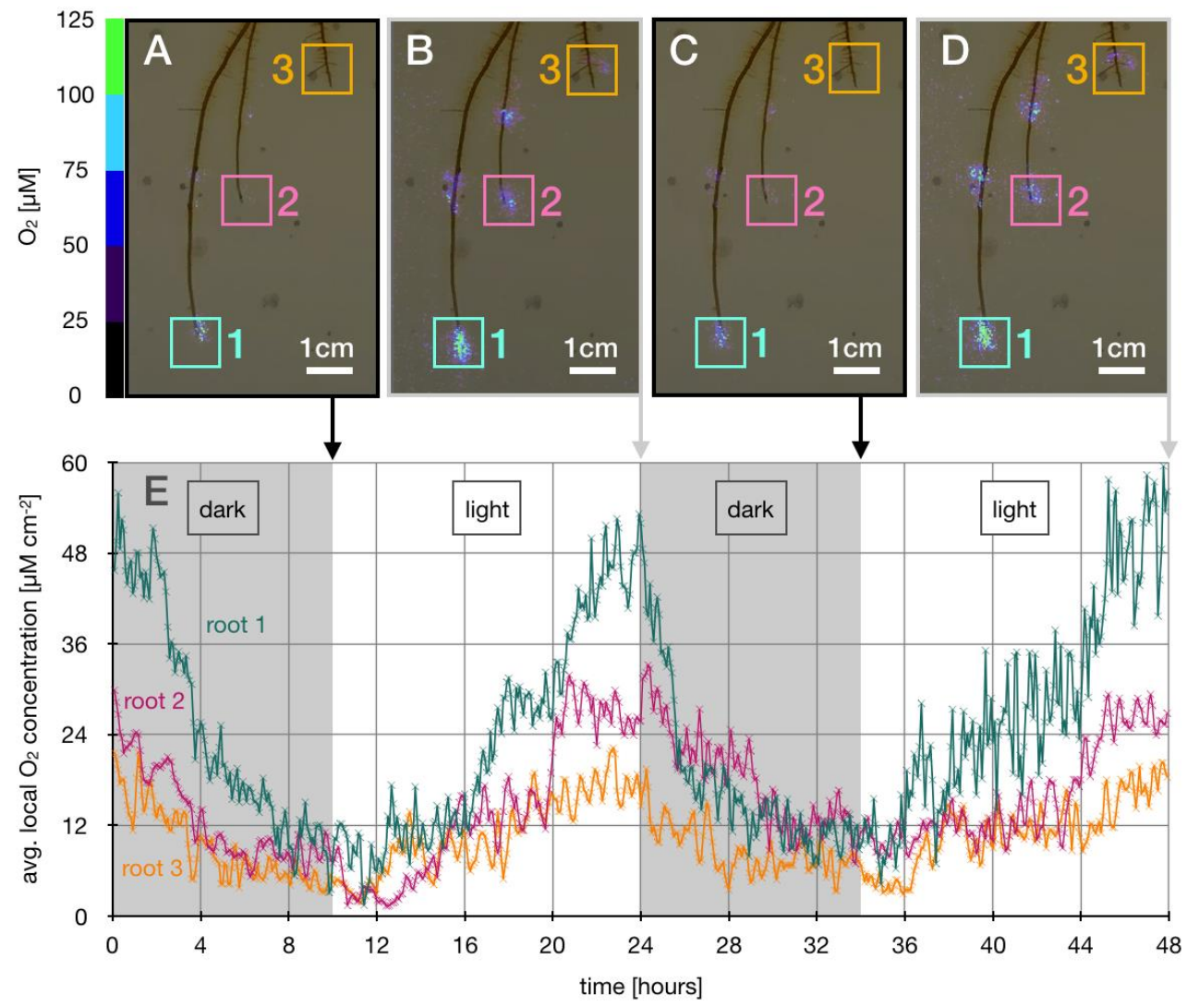

Figure 2. Diurnal changes in local $\mathrm{O}_{2}$ concentrations at root tips. (A-D) illustrate three root tips and local $\mathrm{O}_{2}$ concentrations in the range of $0-125 \mu \mathrm{M} \mathrm{O}_{2}$ represented as color coded pixels. Colored squares 1-3 represent areas around root tips $\left(1.0 \mathrm{~cm}^{2}\right)$ where local $\mathrm{O}_{2}$ concentrations were quantified at the end of dark $(10 \mathrm{~h})$ and light $(14 \mathrm{~h})$ incubated cycles, respectively. (E) displays averaged measured local $\mathrm{O}_{2}$ concentrations over time, measured in time intervals of $5 \mathrm{~min}$ for each root tip area 1-3, respectively.

Table 1. Responses of local root tip $\mathrm{O}_{2}$ concentrations to diurnal cycles. Changes in local $\mathrm{O}_{2}$ concentrations $\left(\Delta \mathrm{O}_{2}\right.$ local) at three designated root tips (roots 1-3) and average changes during dark $(10 \mathrm{~h})$ and light $(14 \mathrm{~h})$ incubation.

\begin{tabular}{ccc}
\hline$\Delta \mathbf{O}_{\mathbf{2}}$ Local Concentration at Root Tip & Dark $\left(\boldsymbol{\mu} \mathbf{M}\right.$ hour $\left.{ }^{-\mathbf{1}}\right)$ & ${\text { Light }\left(\boldsymbol{\mu M} \mathbf{~ h o u r}^{-\mathbf{1}}\right)}$ \\
Root 1 & $-3.8( \pm 0.6)$ & $+3.2( \pm 0.8)$ \\
Root 2 & $-2.4( \pm 0.4)$ & $+2.0( \pm 0.3)$ \\
Root 3 & $-1.9( \pm 0.3)$ & $+0.9( \pm 0.2)$ \\
Average & $-2.7( \pm 1.0)$ & $+2.0( \pm 1.2)$ \\
\hline
\end{tabular}

\subsection{Iron Plaque Mineral Formation and Transformation}

The release of $\mathrm{O}_{2}$ from roots lead to the oxidation of $\mathrm{Fe}(\mathrm{II})$ and the formation of ferric iron minerals on the root surface across the entire rhizosphere. Following analysis of rhizosphere images, we observed that after 3 DAT freshly precipitated orange-colored iron plaque minerals formed on young roots (Figure S1B-G, Supporting Information). Following root growth and iron plaque mineral formation over 45 days, both the average total root surface area and surface area of root iron plaque increased significantly following a linear trend over time (Figure 3A; Figure S1A, Supporting Information) with an averaged formation of $4.3 \mathrm{~cm}^{2}$ root surface area $\left(R^{2}=0.97\right)$ and $1.7 \mathrm{~cm}^{2}$ iron plaque surface area 
$\left(R^{2}=0.98\right)$ precipitating per day. However, among all replicate setups, the ratio of iron plaque covered to non-covered root surface area widely varied within 30 DAT ranging from $<15 \%$ to more than $50 \%$ of the total root surface covered in iron plaque precipitates (Figure 3B). Yet, towards the end of the experiment after $45 \mathrm{DAT}$, on average $36( \pm 2.6) \%$ of the total root surface area in all setups were covered in iron plaque minerals which corresponds to an average root iron plaque surface area of $75( \pm 13.6)$ $\mathrm{cm}^{2}$ per plant at the end of the experiment.
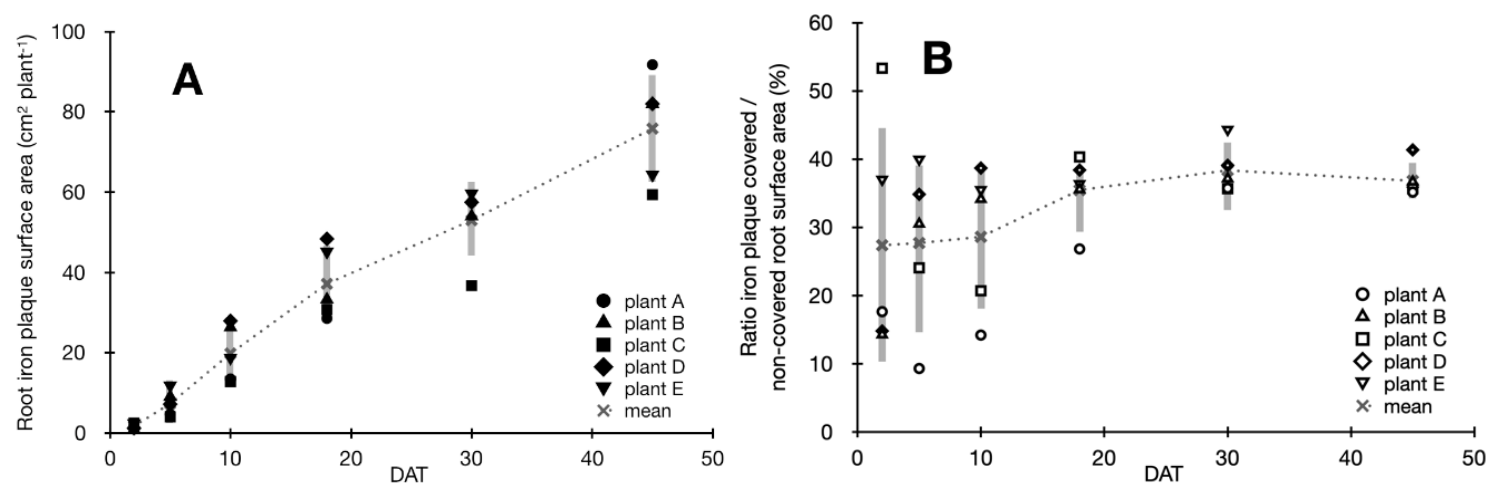

Figure 3. Root iron plaque formation during plant growth. (A) Iron plaque mineral surface ( $\mathrm{cm}^{2}$ per plant) on roots during plant growth (DAT = days after transfer) of five replicate plants (filled symbols), mean root iron plaque surface area (cross \& punctuated line) and standard deviation (grey bars); (B) Ratios of iron plaque-covered to non-covered root surface area (\%) in rhizotrons during plant growth over 45 DAT, averaged ratio of all replicates (cross and punctuated line) and standard deviation (grey bars).

Iron plaque minerals collected at the end of the growth experiment from (i) the basal root zone (approx. 40 days old), (ii) the middle part of the root (approx. 20 days old), and (iii) the root tips (freshly formed iron plaque) differed substantially in their mineralogical composition. The oldest root iron plaque minerals showed the highest degree in crystallinity with $15 \%$ goethite, approx. $10 \%$ lepidocrocite and some resilient ferrihydrite (Figure 4; Figure S2A; Table S1). Root iron plaque minerals collected from the middle part of the root section were composed of $25 \%$ lepidocrocite, approx. $70 \%$ ferrihydrite and 5\% goethite only (Figure 4; Figure S2B; Table S1). Freshly formed iron plaque collected from root tips was dominated by $>95 \%$ ferrihydrite and a small fraction of approx. $4 \%$ potentially sorbed/complexed Fe(II) (Figure 4; Figure S2C; Table S1).
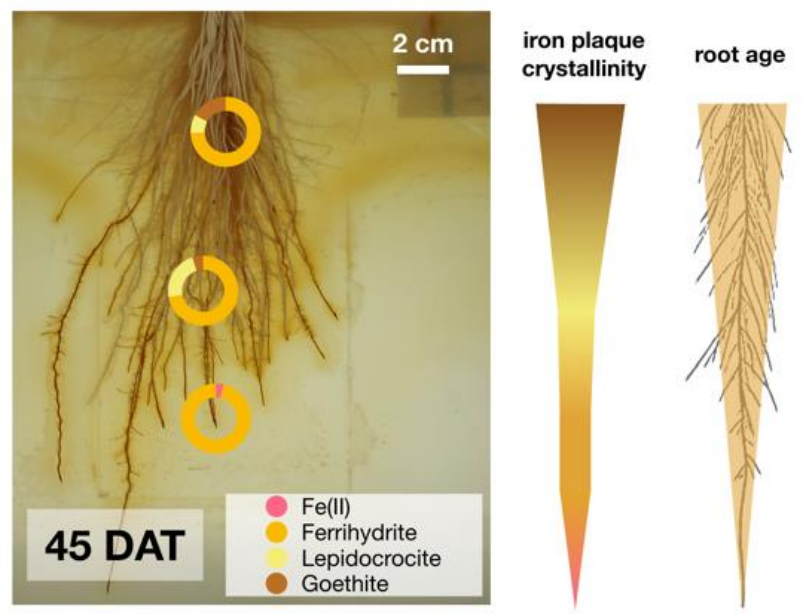

Figure 4. Iron plaque collected from different root sections, young root tip, middle part (approx. 20 days old) and basal root zone (approx. 40 days old) showed increasing iron mineral crystallinity which correlated positively to root age. 


\subsection{Iron Plaque Reduction, Mineral Transformation, and Reductive Dissolution}

In order to quantify the extent of iron plaque that can be reduced and remobilized microbially, roots from rice plants that were covered with iron plaque minerals were exposed to an $\mathrm{Fe}(\mathrm{III})$-reducing enrichment culture isolated from a paddy field (Vercelli, Italy; 99.8\% identity to Geobacter sp. CD1 [39] based on $16 \mathrm{~S}$ rRNA). Within $24 \mathrm{~h}$, iron plaque minerals in biotic setups changed in color from orange to black, while abiotic control incubations remained orange (Figure 5A). In biotic setups, dissolved $\mathrm{Fe}(\mathrm{II})$ concentrations increased significantly from initially $<10 \mu \mathrm{M} \mathrm{Fe}(\mathrm{II})$ to $730( \pm 130) \mu \mathrm{M} \mathrm{Fe}(\mathrm{II})$ after $24 \mathrm{~h}$ which translates to an Fe(II) remobilization rate of $15 \mu$ moles per hour. In the inhibited control incubation, $\mathrm{Fe}$ (II) concentrations remained constant throughout the experiment with $\mathrm{Fe}$ (II) concentrations $<50 \mu \mathrm{M}$. Following $43 \mathrm{~h}$ of incubation, Fe(II) concentrations declined by approx. $15 \%$ in biotic incubations and leveled off at constant concentrations of around $550 \mu \mathrm{M} F e($ II) until the end of the incubation after $185 \mathrm{~h}$ (Figure 5B).
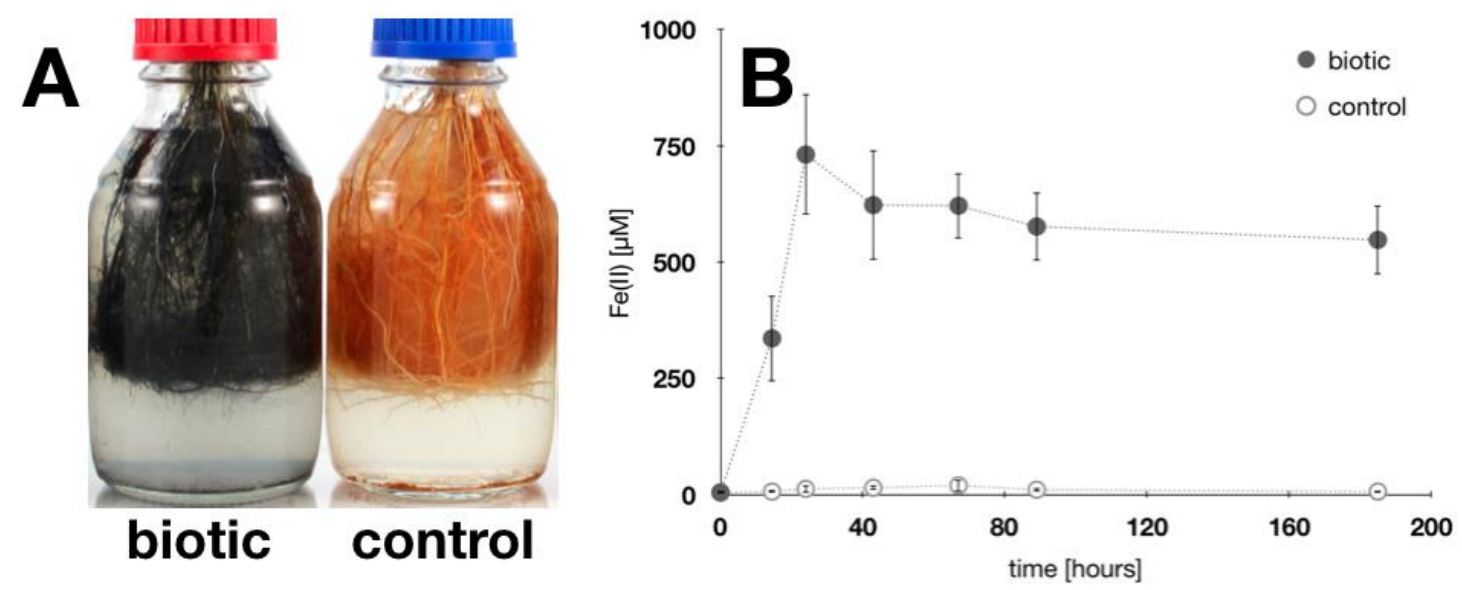

Figure 5. Root iron plaque reduction. (A): Root iron plaque exposed for $24 \mathrm{~h}$ to an Fe(III)-reducing enrichment culture (99.8\% similarity to Geobacter spp.). Iron plaque minerals changed from orange (control) to black (biotic) during incubation. (B): Dissolved Fe(II) concentrations in medium during iron plaque reduction. Iron(III) plaque minerals were reduced and Fe(II) remobilized through microbial reductive dissolution. Error bars represent experimental standard deviation from six replicate setups.

During microbial reduction, also the iron plaque mineralogy changed considerably. After $185 \mathrm{~h}$, a sample was collected from biotic and control incubations. Mössbauer spectroscopy demonstrated that iron minerals in the control incubation can be identified as $90 \%$ ferrihydrite and $10 \%$ lepidocrocite (Figure S3A). On the contrary, in active Fe(III)-reducing incubations, more than $80 \%$ of the remaining iron plaque on the root surface was composed of Fe(II) minerals (e.g., $70 \% \mathrm{Fe}$ (II) (oxyhydr)oxides and $10 \% \mathrm{Fe}$ (II)-sulfur species), while only $20 \%$ of the root iron plaque minerals remained as $\mathrm{Fe}(\mathrm{III})$ (oxyhydr)oxide identified to be ferrihydrite (Table S2; Figure S3B). Iron mineral extractions after the incubation confirmed that $20-29 \%$ of the total initial iron plaque (ranging from $60.2-189.0 \mathrm{mg} \mathrm{g}^{-1} \mathrm{dry}$ root weight, mean $117.4( \pm 23.0) \mathrm{mg} \mathrm{g}^{-1}$ dry root weight) was remobilized as Fe(II) during microbial incubation (Table 2).

Table 2. Iron plaque formation, remobilization, and transformation during microbial Fe(II) reduction.

Total iron plaque mineral formation on roots was quantified by mineral extraction.

\begin{tabular}{|c|c|c|c|}
\hline & $\begin{array}{l}\text { Total Root Iron Plaque } \\
\text { (mg Fe g }{ }^{-1} \text { Dry Root } \\
\text { Weight, (Mean)) }\end{array}$ & $\begin{array}{c}\text { Iron Plaque Remobilization } \\
\text { (mg Fe } \mathrm{g}^{-1} \text { Dry Root Weight (\%)) }\end{array}$ & $\begin{array}{l}\text { Iron Plaque Fe(II)/Fe(III) } \\
\text { Ratio after Incubation (\%) }\end{array}$ \\
\hline Remobilization Ratio & $60.2-189.0(117.4 \pm 23.0)$ & $23.4-58.6(20-29)$ & $73-85$ \\
\hline
\end{tabular}




\subsection{Spatio-Temporal Iron Plaque Reduction, Fe(II) Remobilization, and Rhizosphere Gradients}

Roots covered in iron plaque were exposed to the Fe(III)-reducing enrichment culture and incubated in transparent growth gel in order to spatio-temporally follow Fe(III)-reduction and remobilization of $\mathrm{Fe}(\mathrm{II})$ from roots. After 3 days, black colored iron plaque was observed in a heterogeneous pattern and constituted approximately $50 \%$ of the total iron plaque on roots (Figure 6). Changes in color from initially orange minerals to dark phases were previously demonstrated to indicate Fe(III) reduction and mineral transformation. Over the following days, black minerals dominated root iron plaque and expanded over the entire root biomass (Figure 6A-D). After 10 days of incubation, the entire root biomass was fully covered in black minerals (Figure 6E). Dissolved Fe(II) was measured voltammetrically along a transect through the rhizosphere to quantify dissolved Fe(II) as a product of reductive dissolution of iron plaque. Concentrations of $\mathrm{Fe}(\mathrm{II})$ varied to a large extent from $<500 \mu \mathrm{M}$ at positions without roots to high concentrations reaching $>1.5 \mathrm{mM} \mathrm{Fe}$ (II) close to roots covered in black precipitates (Figure $6 \mathrm{~F}$ ). Reduced iron plaque minerals were analyzed by Mössbauer spectroscopy as identified as similar mineral phases (as Fe(III) mineral vivianite, potentially Fe(II)-S phase and some resilient ferrihydrite) as previously observed in liquid culture iron plaque reduction experiments (Table S3; Figure S4).
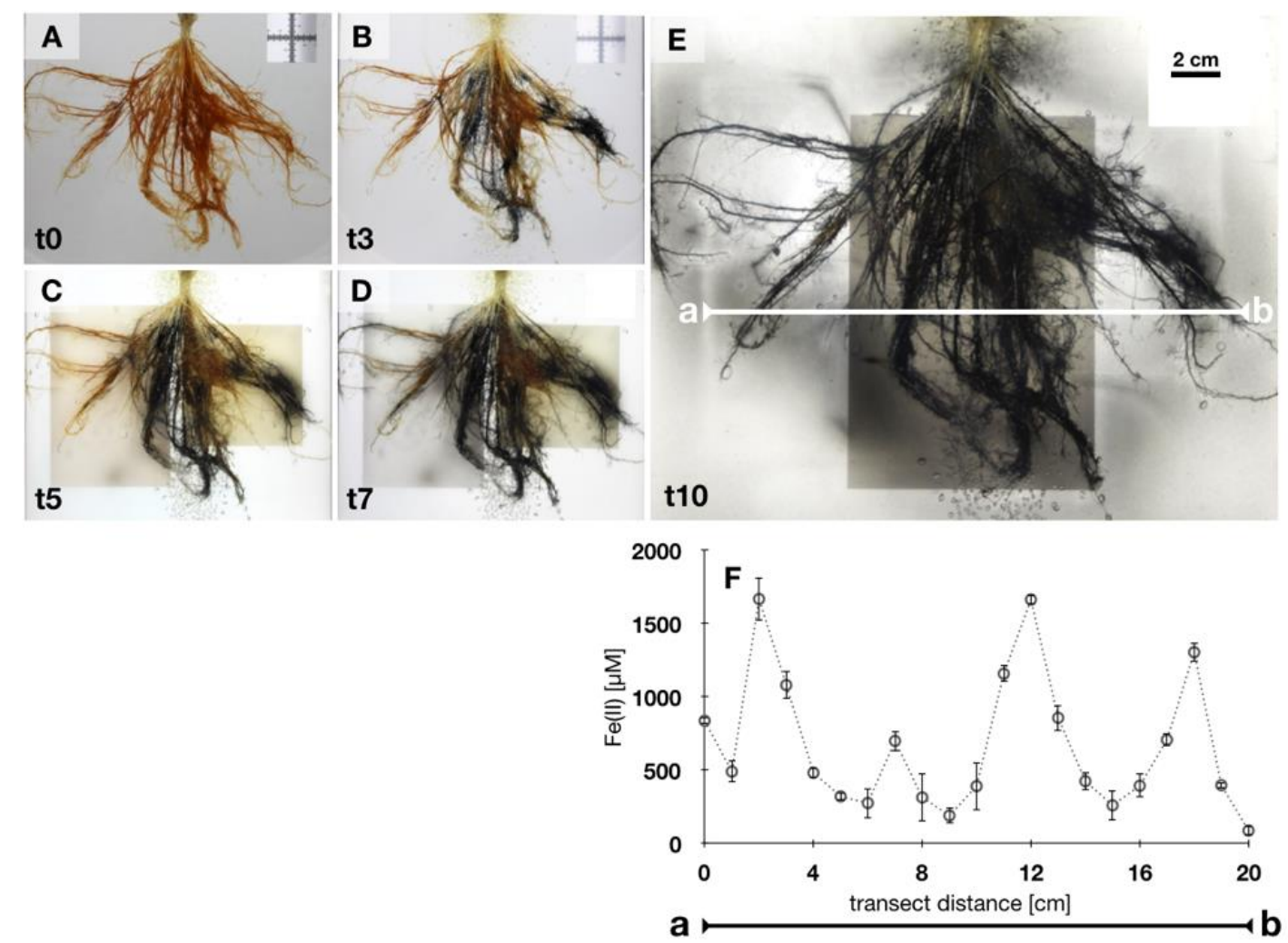

Figure 6. Microbial Fe(III) iron plaque reduction. (A-E): Roots covered with iron plaque minerals incubated in rhizotron with an $\mathrm{Fe}(\mathrm{III})$-reducing enrichment culture. Iron plaque minerals change in color over time $\mathrm{A}, \mathrm{t} 0$ : day $0-\mathrm{E}, \mathrm{t} 10$ : day 10 . (F): Voltammetric measurements along transect $\mathrm{a}-\mathrm{b}$ in setup of figure, after 10 days of incubation, detect Fe(II) remobilized from root iron plaque is closely associated with roots. Error bars represent standard deviation from triplicate voltammograms.

\section{Discussion}

\subsection{Rice Roots as Initiator for Rhizosphere Iron Mineral Formation and Heavy Metal Immobilization}

Research interest in iron plaque on rice roots raised significantly over the last decades [24-26,28]. Numerous studies impressed with estimates derived from laboratory and field observations attempting to explain the sorption of soil components to iron plaque and quantifying the iron plaque immobilization 
capacity for contaminants [24-28]. The results in the current study aim to complement the understanding of rice roots as an important driver for the formation of soil iron minerals. Here, we found that an averaged total of approx. $75 \mathrm{~cm}^{2}$ per plant iron plaque surface area was calculated to have formed on the root surface until the end of the growth cycle after 45 DAT (Figure 7). It has been previously observed that root iron plaque can form on roots of rice plants and form a thick layer between 20-40 $\mu \mathrm{m}[41,42]$. Given the calculated iron plaque surface area and the range of reported iron plaque layer thickness, the resulting volume of iron plaque that can form on the roots until 45 DAT was calculated to reach values between $150 \mathrm{~mm}^{3}$ to $300 \mathrm{~mm}^{3}$ per plant. Since ferrihydrite was the most dominant iron mineral species identified in the iron plaque in our setups, the density of ferrihydrite of $\rho_{\mathrm{Fh}}=3.8 \mathrm{~g} / \mathrm{cm}^{3}$ [43] was considered as an estimate for the density of all iron minerals that formed as root iron plaque. This estimate results in a total of $570 \mathrm{mg}$ to $1140 \mathrm{mg}$ of ferrihydrite that can theoretically form on the root surface of one plant within 45 DAT. Considering that ferrihydrite consists of approx. 70 atomic weight \% of iron atoms, this results in a net mass of around $400 \mathrm{mg}$ to $800 \mathrm{mg}$ iron that precipitated as iron minerals on the roots of each rice plant within only 45 days. In comparison with the observed linear trend of averaged $1.7 \mathrm{~cm}^{2}$ root iron plaque surface area being formed per day, which corresponds to a volume of up to $5.1 \mathrm{~mm}^{3}$ root iron plaque, we estimated that $20 \mathrm{mg}$ ferrihydrite (which represents approx. $14 \mathrm{mg}$ soil-borne iron) can precipitate daily on the root surface of one single rice plant. Evidently, this large number of iron minerals that can precipitate on the root surface has broad consequences not only for the immobility of soil-borne iron but the biogeochemical cycling of iron in paddy soils. With around $80-100$ rice plants conventionally planted per square meter of paddy soil, more than $1.2 \mathrm{~g}$ soil-borne iron can precipitate on rice roots within one cubic meter of flooded paddy soil per day. A paddy field in south east Asia, that is commonly characterized by $20-50 \mathrm{~g}$ iron per $\mathrm{kg}$ wetted soil [14,44] and an averaged bulk density of approx. $1.5 \mathrm{~g} / \mathrm{cm}^{3}$ [45], can contain between $3 \times 10^{4}-7.5 \times 10^{4} \mathrm{~g}$ iron per $\mathrm{m}^{3}$ soil. Following the concept and the constant availability of dissolved $\mathrm{Fe}(\mathrm{II})$, rice plants would have the potential to daily affect between $2-5 \mathrm{ppm}$ of the total soil by iron plaque formation. Considering the medium duration of 120-140 days per growing season, the roots of rice plants would theoretically be able to precipitate 156-182 $\mathrm{g}$ iron as root iron plaque minerals per growing season within one cubic meter soil, which represents a maximum of approx. $0.6 \%$ of total iron budget in a paddy soil. Although $0.6 \%$ seems to represent only a small fraction of the total iron budget in a paddy field, the consequences for the retention of dissolved substances, such as nutrients, (cat)ions, or contaminants might be significantly impacted. The total surface area of iron plaque minerals that can form under the hypothesized conditions increases daily by $170 \mathrm{~cm}^{2}$ per $\mathrm{m}^{3}$ paddy soil when 100 plants are planted. Ideal ferrihydrite in particular, is dominated by singly-coordinated surface groups with a reported number of $6.0 \pm 0.5 \mathrm{~nm}^{-2}$ [43]. Consequently, a formation of $170 \mathrm{~cm}^{2}$ iron plaque surface area provides a total number of $1.02 \times 10^{17}$ singly-coordinated surface groups where dissolved ions in the pore water, such as phosphate, carbonate, and heavy metals, i.e., arsenite or arsenate can build a Stern layer [46] and form inner-sphere complexes with the root iron (oxyhydr)oxides.

The formation of plant-induced iron (oxyhydr)oxide minerals in the soil horizon could theoretically also impact the retention of other soil constituents and metal(loid)s such as arsenic. In other words, under the theoretic assumption that one dissolved soil-borne ion can bind to one surface group of root plaque ferrihydrite, the observed formation of root iron plaque on the roots of rice plants could provide surface sites for approx. $0.2 \mu$ moles dissolved ions per day within one $\mathrm{m}^{3}$ of paddy soil. Typically, paddy fields contaminated with arsenic contain up to $150 \mu \mathrm{g}$ arsenic $(=2 \mu \mathrm{M})$ per liter pore water. Given an effective soil porosity of 0.25 , which is commonly observed in wetted paddy fields [47], the pore water of $1 \mathrm{~m}^{3}$ paddy soil can effectively contain $500 \mu$ moles of arsenic ions. Based on these assumptions and the observed root iron plaque formation from the current study, the roots of 100 rice plants on one $1 \mathrm{~m}^{2}$ paddy field would have the potential to form iron mineral surface sites that can bind and immobilize up to $20 \mu$ moles of arsenic per growing season, which corresponds to approx. $5 \%$ of the total dissolved arsenic in $1 \mathrm{~m}^{3}$ contaminated paddy soil. In addition to one layer of inner-sphere complexes, also outer-sphere adsorption complexes might play an important role in 
arsenic immobilization and even increase the root iron plaque sorption capacities for arsenic ions [48]. On the contrary, it is worth mentioning that root iron plaque mineral surfaces will not exclusively be occupied by arsenic ions only. A large variety of dissolved and mobile soil components, such as phosphate, magnesium, soil organic matter and other chelating compounds [49] might compete for surface binding sites on the root iron plaque and potentially decrease the net amount of arsenic binding to root iron plaque. Moreover, as ferrous iron concentrations in rice paddies can vary to a large extent, the reported estimates for the formation of root iron plaque minerals potentially only apply for soil parameters with similar, rather elevated, iron concentrations. In paddy soils with a relatively high abundance of clay minerals, dissolved Fe(II) concentrations were reported to be lower, thus diminishing the formation of root iron plaque minerals. Consequently, our assumptions might represent only a conservative estimate for the potential of root iron plaque to immobilize arsenic from the pore water. However, these findings can help to serve as a guideline for an approximation of contaminant (im)mobility in paddy fields which is lacking so far. Moreover, the estimated extent of roots in forming soil iron minerals by aerobic redox reactions and the capability to immobilize dissolved soil constituents demonstrate the impact rice plants can have on the oxidative side of the iron biogeochemical cycle in paddy fields.

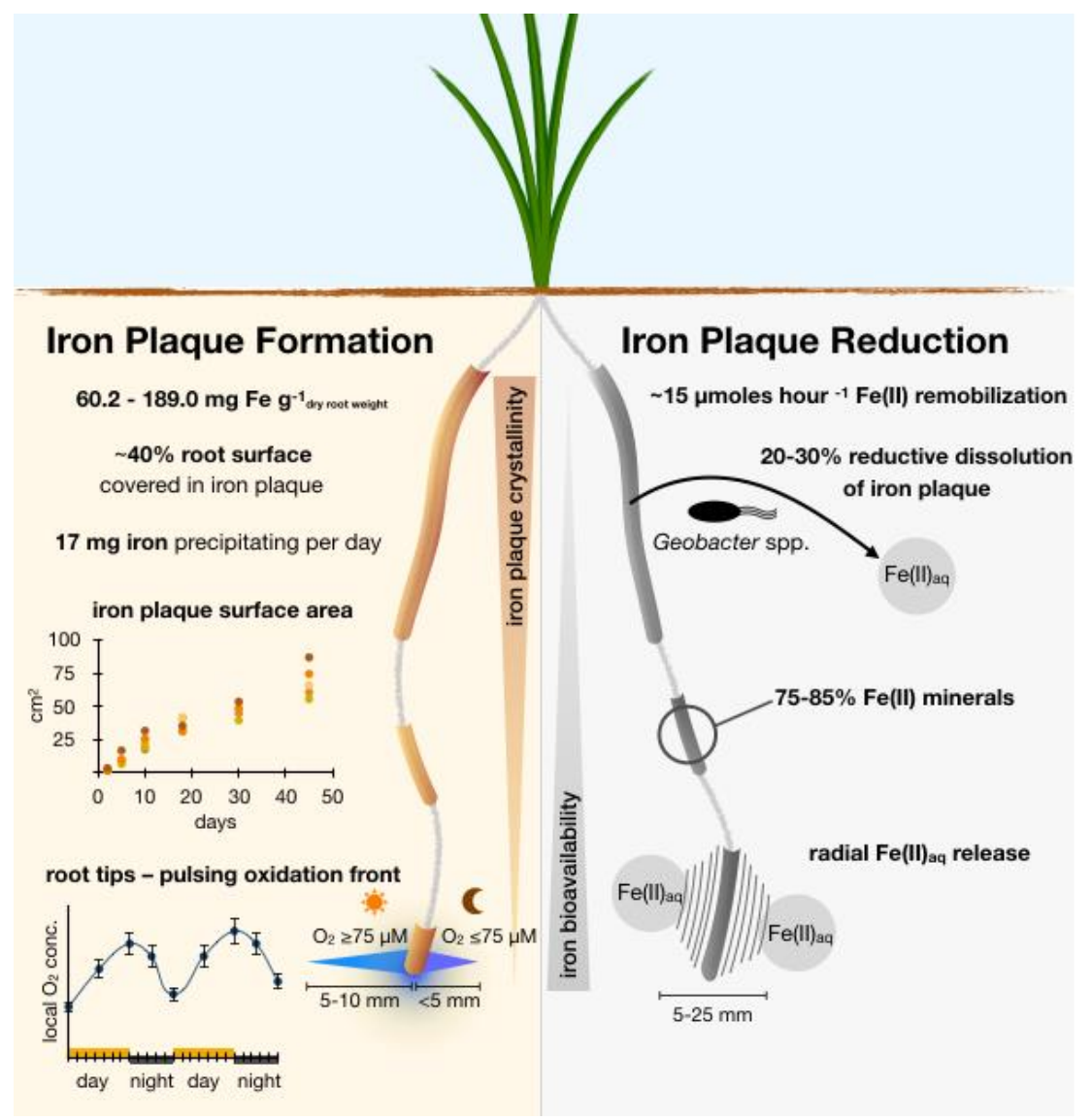

Figure 7. Summary of biogeochemical processes observed in this study that affect the rhizosphere iron cycle at and around rice roots covered in root iron plaque. (Left): Oxidative side of the outlined rhizosphere iron cycle with estimates for an immobilization of iron per gram dry weight rice root, root iron plaque coverage, and diurnal changes in ROL at root tips that affect local redox conditions. (Right): Reductive side of the proposed rhizosphere iron cycle with observed rates and extent for root iron plaque remobilization through reductive dissolution and reductive mineral transformation by the Geobacter spp. culture used in the current study, affecting iron plaque crystallinity and bioavailability, respectively. 


\subsection{Impact of Microaerophilic Fe(II)-Oxidizers on Iron Plaque Formation}

Several studies proposed that $\mathrm{Fe}(\mathrm{II})$ oxidation and iron mineral formation in wetland soil ecosystems are abiotic processes $[50,51]$ driven by ROL only. However, field studies demonstrated that neutrophilic Fe(II)-oxidizing bacteria are associated with roots covered in iron plaque $[17,29,52]$ and additional studies under laboratory-controlled conditions showed these bacteria can actively contribute to $\mathrm{Fe}(\mathrm{II})$ oxidation [33] while others quantified that these bacteria can even enhance root iron plaque formation by up to $40 \%$ [18]. Weiss et al. (2003) [29] observed that a low abundance of microaerophilic $\mathrm{Fe}(\mathrm{II})$-oxidizing bacteria co-occurred even with the lowest iron plaque formation on roots of wetland plants. Although complex geochemical dynamics in paddy soils are hard to decipher, we recently showed that the habitats for microaerophilic Fe(II)-oxidizing bacteria in a rice plant rhizosphere are highly dynamic in space and time and that these bacteria find ideal conditions in the entire rice plant rhizosphere [19]. This observation is supported by findings from Weiss at al. 2003 [29] who found that the relative abundance of microaerophilic Fe(II)-oxidizing bacteria in the rhizosphere exceeded the abundance in bulk soil. However, even without a contribution of microaerophilic Fe(II)-oxidizing bacteria, large amounts of ferric minerals formed along the roots and covered more than $30 \%$ (Figure 3; Figure S1B) of the root surface with more than $60 \mathrm{mg} \mathrm{g}^{-1}$ dry root weight precipitation on the roots. Taking into account the $30 \%$ of plant root surface area which was affected by ROL and iron plaque formation, given the reported numbers of microaerophilic Fe(II)-oxidizing bacteria in wetland soils ranging from $7.1 \times 10^{2}-1.1 \times 10^{6} \mathrm{~g}^{-1}$ dry weight soil (up to $4.1 \times 10^{5}$ cells $\mathrm{cm}^{-3}$ soil) [29] and the reported $\mathrm{Fe}(\mathrm{II})$ oxidation rates for a large variety of microaerophilic $\mathrm{Fe}(\mathrm{II})$-oxidizing bacteria ranging from 1.0-8.3·10 ${ }^{-16}$ mol Fe(II) cell ${ }^{-1}$ hour $^{-1}[18,33,53,54]$, net microaerophilic Fe(II) oxidation can conservatively be estimated to oxidize between $4.1 \times 10^{-11}$ to $3.4 \times 10^{-10} \mathrm{~mol} \mathrm{Fe}$ (II) $\mathrm{cm}^{-3}$ (0.04 to $0.34 \mathrm{mmol} \mathrm{Fe}(\mathrm{II}) \mathrm{m}^{-3}$ ) wetland soil per hour regarding the highest reported cell numbers from paddy fields. This amount of microaerophilically induced iron mineral formation could result in a total of 0.03 to $0.4 \mathrm{~g}$ iron mineral precipitation within one $\mathrm{m}^{3}$ paddy soil per day under optimum conditions. Compared to the finding that more than $1.2 \mathrm{~g}$ soil-borne iron that can precipitate on rice roots within one cubic meter of flooded paddy soil per day, the impact of biogenic microaerophilic Fe(II) oxidation can vary to a large extent but has the potential to enhance net total iron mineral formation in the rhizosphere by approx. 3-30\%. On the contrary, the microbial oxidation of soil-borne Fe(II) and the sequestration of $\mathrm{O}_{2}$ by these bacteria could potentially reduce abiotic oxidation kinetics and diminish the role of plant-mediated iron plaque formation, suggesting that the net contribution to $\mathrm{Fe}(\mathrm{II})$ oxidation can be even more attributed to the microbial activity.

Considering that reported cell numbers for microFeOx were likely underestimated [29] due to the fact that $<1 \%$ of soil microbial community is cultivatable under laboratory conditions, the absolute number of microFeOx in the environment might be even higher and the calculated impact underestimated. On the contrary, in the environment numerous other complex biogeochemical processes (e.g., nitrate-dependent $\mathrm{Fe}(\mathrm{II})$ oxidation, annamox, oxidizing chelators) can contribute to the oxidative side of the rhizosphere iron cycle, compete with microaerophilic Fe(II) respiration [55] and lower the effective impact of microaerophilic Fe(II) oxidation which cushions their role in iron mineralization. On the contrary, the sequestration of $\mathrm{O}_{2}$ from ROL by microaerophilic $\mathrm{Fe}(\mathrm{II})$-oxidizing bacteria might diminish local $\mathrm{O}_{2}$ concentrations surrounding individual roots. Both the production of ferric biominerals, as a product of microbial $\mathrm{Fe}(\mathrm{II})$ oxidation, and the depletion in $\mathrm{O}_{2}$ might create suitable conditions for $\mathrm{Fe}(\mathrm{III})$-reducing microorganisms usually sensitive to $\mathrm{O}_{2}$. These bacteria could be attracted into the redox-active zone in the vicinity of the roots and conserve metabolic energy by microbially reducing the ferric minerals produced by microaerophilic Fe(II)-oxidizers. However, these assumptions might represent only an ideal and vague estimate. Nevertheless, the reported observations can help to complement the quantitative understanding of the microaerophilic rhizosphere iron cycle and shed light on a yet potentially underestimated plant-microbe interaction that can effectively contribute to iron mineral deposition in flooded paddy fields. 


\subsection{Root Iron Plaque as a Hot Spot for Fe(III) Reduction}

In this context, it is worth mentioning that Fe(III) minerals also represent an ideal electron acceptor for numerous Fe(III)-reducing bacteria [13]. Especially poorly crystalline Fe(III) oxides (such as ferrihydrite) that have been observed on the roots of rice and numerous other wetland plants growing in natural settings [7] were speculated to favor the high abundances of Fe(III)-reducing bacteria in wetland rhizospheres [56,57]. In particular, associated with roots, these Fe(III)-reducing microorganisms showed a significantly higher relative abundance in the rhizosphere $(>10 \%)$ compared to bulk soil [57]. In practice, acetate and plant-derived root exudates are readily bioavailable carbon sources and widely found in the vicinity of roots of numerous wetland plants [58-60]. For such reasons, roots covered in ferric iron minerals also represent an ideal habitat for Fe(III)-reducing bacteria, such as Geobacter spp., that can couple the oxidation of these fatty acids and organics to the reduction of root $\mathrm{Fe}(\mathrm{III})$ plaque $[57,61]$. With the current findings, it is now realized that Geobacter spp. is capable of remobilizing more than $30 \%$ of the iron plaque minerals within a relatively short time $(<24 \mathrm{~h}$; Figure 5 , Table 2). Given the rate of more than $15 \mu$ moles Fe(II) per hour being released by reductive dissolution, this demonstrates that $\mathrm{Fe}(\mathrm{III})$-reducing bacteria can have a huge impact on the remobilization and transformation of iron plaque minerals. This remobilization by reduction was in focus of a large variety of observations. Historical examples include a study by King and Garey (1999) [56] which is probably one of the first studies that found ecologically relevant reduction of iron from around $4.5 \mathrm{mg}$ Fe per $\mathrm{g}^{-1}$ dry root weight of wetland plants. They observed that iron was only reduced under anoxic conditions and consolidated the importance of microbial Fe(III) reduction for the iron redox cycling in water-logged temperate environments. Presently, our findings showed that microbial Fe(III) reduction can not only contribute significantly to Fe(III) plaque reduction (by up to $70 \%$ ) but considerably impact $\mathrm{Fe}(\mathrm{II})$ remobilization from iron plaque with more than $23 \mathrm{mg}$ Fe(II) being released per plant within less than $48 \mathrm{~h}$ (Figure 5). Most remarkable yet was that iron plaque minerals which were found to be microbially reduced showed highest concentrations radially spread in the close vicinity of the root surface and only little mobility $(10-25 \mathrm{~mm}$ ) in the artificial soil matrix (Figure 6). This suggests that the reduction of ferric iron minerals and the remobilization of one-third of the initial iron plaque precipitates as Fe(II) to the vicinity of the root surface can fuel, e.g., microbial Fe(II) oxidation, only in a small redox active microenvironment closely (within $25 \mathrm{~mm}$ ) surrounding the root surface.

While young roots showed predominantly low-crystalline ferrihydrite as freshly precipitated iron plaque, a relatively high proportion of $>20 \%$ lepidocrocite and goethite was found on older (approx. 42 days old) roots (Figure 4). These transitions in iron mineralogy suggest that the degree in iron plaque crystallinity correlates positively to root age (Figure 7). Generally, such time-dependent changes in crystallinity are commonly observed to be the result of mineral transformation processes, referred to as Ostwald ripening [62]. Under environmental aspects, these changes in iron plaque mineralogy not only affect surface properties of the iron plaque itself but also decrease sorption capacities for, e.g., nutrients and contaminants. A decrease in sorption capacities, as it was observed for higher crystalline iron minerals, can have drastic negative effects on contaminant retention [63-65]. Moreover, the higher relative abundance of more crystalline iron plaque minerals was demonstrated to decrease the bioavailability for microbial Fe(III) reduction $[66,67]$ and thus the remobilization rate of iron plaque-derived $\mathrm{Fe}(\mathrm{II})$. We therefore conclude that, with time, iron plaque minerals are becoming more recalcitrant towards (abiogenic and microbial) Fe(III) reduction and that the microbial bioavailability correlates negatively with root age. In doing so, microbial processes, such as Fe(III) reduction and reductive dissolution, might be inhibited by the abundance of more crystalline iron mineral phases shifting the dominance in impacting the iron plaque reduction to more prevalent abiotically-induced reducing processes, such as by humic acids or other plant-derived complexing compounds. This hypothesis is strongly supported by findings from Roden et al. 1996 [68] and recently from Najem et al. (2016) [69] who observed a significantly lower microbial Fe(III) reduction rate for $\mathrm{Fe}(\mathrm{III})$-reducing bacteria grown on aged or higher-crystalline iron minerals compared to growth on freshly precipitated ferrihydrite. We therefore suspect that while the crystallinity of root iron 
plaque minerals increases with root age, the availability to serve as a substrate for Fe(III)-reducing bacteria gradually decreases during plant growth (Figure 7). Under these circumstances, we conclude that young roots (i.e., root tips) may represent a highly dynamic iron redox hot spot. Here, freshly precipitated low-crystalline iron plaque minerals can form which immediately serve as ideal substrate for microbial Fe(III) reduction. Apparently, the bulk root zone is predominantly characterized by more stagnant iron redox conditions due to higher-crystalline iron mineral fractions (Figure 4) and constantly oxygenated conditions which both can inhibit Fe(III) reduction. For such reasons, we suggest that plant induced iron plaque formation, the alteration of minerals, and more importantly, vertical temporal-dynamic iron plaque reduction need to be considered as important parameters for future rhizosphere studies in paddy fields.

\subsection{Root Tips-The Light Dependent Locomotion for Rhizosphere Redox Changes in Paddy Soils}

In addition to the foregoing, we recognized that root tips showed the highest extent in $\mathrm{O}_{2}$ concentration dynamics. During light-incubated cycles, $\mathrm{O}_{2}$ concentrations around root tips increased periodically to concentrations $\mathrm{O}_{2}>100 \mu \mathrm{M}$ expanding the oxidized zones 5-10 mm radially into the anoxic zones. Both, $\mathrm{O}_{2}$ concentrations and the expansion decreased during dark incubated cycles to $\mathrm{O}_{2}$ concentrations $<50 \mu \mathrm{M}$, with a radial expansion of less than $5 \mathrm{~mm}$ around root tips. Along with a stagnation in root growth for 1-3 days, dense ferric iron precipitates settled on the root tip forming a rusty cover on the root cap. As soon as root growth proceeded, the root tip broke through the ferric mineral cover and remained free of any mineral cover before $\mathrm{O}_{2}$ levels increased locally in the following $48 \mathrm{~h}$. The formation of these thick iron plaque covers on the root tips was always accompanied by an increase in ROL from root tip zones, which supports our hypothesis that root tips represent a highly dynamic hot spot for redox reactions such as the oxidation of $\mathrm{Fe}(\mathrm{II})$ and formation of low-crystalline iron plaque minerals. Historically, the oxidizing capacity of root tips in anoxic paddy soils was observed by Flessa et al. (1992) [35] who found that rice root tips can radially (1-4 mm) increase local redox conditions. Most surprising yet in the current study was that the oxidizing capacity of these root tips followed a diurnal pattern that correlated to the availability of light. Consequently, in an otherwise anoxic environment, the root tips can be considered as a redox-active precursor for the oxygenation of the rhizosphere and as a main driver for redox changes in soil-borne iron speciation. More importantly, the root tip-induced $\mathrm{O}_{2}$ availability not only changes iron speciation, but also dominantly affects the soil redox zonation and microbial community shifts throughout the rhizosphere. While the moderate efflux of $\mathrm{O}_{2}$ from root tips $\left(5 \mu \mathrm{M}<\mathrm{O}_{2}<50 \mu \mathrm{M}\right)$ (Figure 1) might create optimum conditions for microFeOx [19,33], also other $\mathrm{O}_{2}$-dependent (bio)geochemical processes may be triggered by the pulsating ROL from root tips. Exemplarily, it was demonstrated that the temporal availability of $\mathrm{O}_{2}$ can trigger heterotrophic microorganisms or aerobic methanotrophs. Consequently, this increase in aerophilic microbial activity can not only increase soil organic carbon turnover, but also decrease $\mathrm{CH}_{4}$ emissions in and from paddy soils [70]. In contrast, regions in the ferric iron plaque minerals with low (no) $\mathrm{O}_{2}$ and the presence of plant exudates (such as chelators and short-chained fatty acids) can then trigger $\mathrm{Fe}(\mathrm{III})$-reducing bacteria sensitive to $\mathrm{O}_{2}$, e.g., Geobacter spp. to thrive their metabolic activity by using low-crystalline Fe(III) plaque minerals as electron acceptor (Figure 5). This dynamic heterogeneity in ROL, rapid local changes in Fe speciation on and around root tips and the spatio-dynamic formation of habitable zones for both aerobic Fe(II)-oxidizing and anaerobic $\mathrm{Fe}(\mathrm{III})$-reducing bacteria that are closely involved in iron plaque redox cycling, prove the so far only speculated importance of the root tips as a precursor for plant-induced redox changes in an otherwise anoxic rice paddy [71].

\subsection{Environmental Relevance}

Biogeochemical iron redox processes that depend on the availability of $\mathrm{O}_{2}$ are linked to the presence of root related ROL that represents the only supply of $\mathrm{O}_{2}$ in water-logged paddy fields. In fact, ROL is not only the main parameter that ultimately triggers ferric iron plaque mineral formation 
but is an essential driver that enables, e.g., neutrophilic microbial microaerophilic Fe(II) oxidation in the rhizosphere [17]. Even so, the availability of $\mathrm{O}_{2}$ from ROL was demonstrated to shift entire soil microbial community composition structures and energy conservation pathways [14]. Examples include Fe(III)-reducing bacteria (such as Geobacter spp.) which are sensitive to $\mathrm{O}_{2}$ [72], would not be able to conserve energy from root $\mathrm{Fe}$ (III) plaque reduction under (micro)oxic conditions as they are prevalent in the close vicinity of the root surface (Figure 1). Microaerophilic Fe(II)-oxidizing bacteria, however, can find their ideal niche conditions in the opposing gradients of soil-borne $\mathrm{Fe}(\mathrm{II})$ and $\mathrm{O}_{2}$ from ROL $[15,17]$ and might even enhance Fe(II) oxidation kinetics [33] and consequently contribute to root iron plaque formation [18]. As shown in the current study, ROL showed extremely high spatial and temporal variation throughout the entire rhizosphere which in turn would shift prevalent conditions favoring (microbial and abiotic) Fe(II) oxidation to Fe(III) reduction and vice versa. Especially during the vegetative growth phase of rice plans, longitudinal $\mathrm{O}_{2}$ diffusion towards the root apex [73] was shown to promote Fe(II) oxidation kinetics and Fe(III) mineral formation at the root tips (Figure 1A,C), while obligate anoxic Fe(III)-reducing bacteria would be inhibited.

In the paddy soil environment, the total root iron mineral surface area which increased with plant age (Figure 2) can consequently affect the retention of nutrients and has the potential to immobilize heavy metals and contaminants to a relevant extent. Moreover, our results imply that they can impact the soil iron budget to a relatively large extent, which can have consequences for a large variety of soil processes, such as methane emissions from paddy fields [74,75], and the preservation of soil organic carbon [76]. The reductive side of the iron redox cycle closes by $\mathrm{Fe}(\mathrm{III})$-reducing reactions that consequently depend on the availability of Fe(III) minerals. These minerals can serve as an electron acceptor for a large variety of microbially-mediated processes such as heterotrophic Fe(III) reduction or abiotically induced $\mathrm{Fe}(\mathrm{III})$ reduction by $\mathrm{H}_{2}$ and other chelating compounds such as plant exudates. Metabolic energy conservation under these conditions is only possible when the pool of $\mathrm{Fe}(\mathrm{II})$ and $\mathrm{Fe}(\mathrm{III})$ is constantly refueled to serve as a microbial electron source or acceptor either way. These findings strongly support our hypothesis that rice roots can considerably impact the biogeochemical iron cycle in water-logged paddy fields. Not only is the oxidative power of the plant root itself catalyzing numerous iron redox processes, but it also serves as an important conductor for $\mathrm{O}_{2}$ that spatio-dynamically enables and disables microbial iron redox reactions. Undoubtedly, the current study investigated rhizosphere processes on a rather simplified analogue to a more complex and interacting rice paddy ecosystem containing numerous other key members interacting with the rhizosphere trinity of plant, soil, and bacteria. However, the current observations extent our understanding in the rhizosphere iron cycling and help to decipher individually that rice plant roots can be one of these key members for both the reductive and oxidative side of the soil-borne iron cycle $[14,58]$. We suggest future research to include similar approaches, increasing the integrity of biogeochemical interactions to fully decipher potential cross-links in the iron cycle between the enormous variety of participants. One potential step towards an understanding of the iron cycle in a more complex rhizosphere system could be the quantitative spatiotemporal investigation of root iron plaque formation incubated in the presence and absence of different members of iron-cycling bacteria, and the availability of soil-extracted soil organic matter or humic substances as metabolic substrate. Moreover, different irrigation practices could also be simulated in future studies. Soil redox conditions in the current setup were maintained constantly anoxic, representing water-logged paddy field. Periodic draining of paddy fields, however, might switch redox conditions to prevalent oxic conditions, suppressing microbial Fe(III) reduction. All these variable parameters taken together, the understanding of this spatio-dynamic small-scale iron redox rhizosphere system can have a huge impact on large scale observations and should be considered for future investigations of the rhizosphere iron redox cycle in paddy fields.

Supplementary Materials: The following are available online at http://www.mdpi.com/2571-8789/4/2/28/s1, Figure S1: Root surface, iron plaque area and evolution of root iron plaque during rice plant growth; Table S1: Mössbauer spectra hyperfine parameters for root iron plaque minerals; Figure S2: Mössbauer transmission spectra of root iron plaque minerals collected at $77 \mathrm{~K}$; Table S2: Mössbauer spectra hyperfine parameters for non/reduced root iron plaque minerals. Figure S3: Mössbauer spectra of root iron plaque reduction experiments measured at 
77 K. Table S3: Mössbauer spectra hyperfine parameters for non/reduced root iron plaque minerals; Figure S4: Mössbauer spectra of root iron plaque reduction experiments in rhizotron measured at $77 \mathrm{~K}$.

Author Contributions: Conceptualization, M.M., A.K. and C.S.; Methodology, M.M.; Software, U.L.; Validation, M.M. and U.L.; Formal analysis, M.M.; Investigation, M.M.; Resources, A.K. and C.S.; Data curation, M.M. and U.L.; Writing—original draft preparation, M.M.; Writing—review and editing, U.L., C.S. and A.K.; Visualization, M.M.; Supervision, C.S.; Project administration, A.K. and C.S.; Funding acquisition, C.S. All authors have read and agreed to the published version of the manuscript.

Funding: This work was funded by DFG Grants SCHM 2808/2-1 and SCHM 2808/4-1 and a Margarete von Wrangell grant to C.S.

Acknowledgments: The study benefited from strong technical support by E. Röhm, L. Grimm (Geomicrobiology, Tuebingen University), and D. Obermaier (PreSens, Regensburg, Germany).

Conflicts of Interest: The authors declare no conflict of interest.

\section{References}

1. Fredrickson, J.K.; Gorby, Y.A. Environmental processes mediated by iron-reducing bacteria. Curr. Opin. Biotechnol. 1996, 7, 287-294. [CrossRef]

2. Begg, C.B.M.; Kirk, G.J.D.; Mackenzie, A.F.; Neue, H.U. Root-Induced Iron Oxidation and Ph Changes in the Lowland Rice Rhizosphere. New Phytol. 1994, 128, 469-477. [CrossRef]

3. Taylor, S.E.; Terry, N.; Huston, R.P. Limiting Factors in Photosynthesis.3. Effects of Iron Nutrition on the Activities of 3 Regulatory Enzymes of Photosynthetic Carbon Metabolism. Plant Physiol. 1982, 70, 1541-1543. [CrossRef] [PubMed]

4. Terry, N. Limiting Factors in Photosynthesis.1. Use of Iron Stress to Control Photo-Chemical Capacity In vivo. Plant Physiol. 1980, 65, 114-120. [CrossRef] [PubMed]

5. Becker, M.; Asch, F. Iron toxicity in rice-conditions and management concepts. J. Plant Nutr. Soil Sci. 2005, 168, 558-573. [CrossRef]

6. Armstrong, W. Oxygen Diffusion from Roots of Rice Grown under Non-Waterlogged Conditions. Physiol. Plant. 1971, 24, 242-247. [CrossRef]

7. Yamaguchi, N.; Ohkura, T.; Takahashi, Y.; Maejima, Y.; Arao, T. Arsenic Distribution and Speciation near Rice Roots Influenced by Iron Plaques and Redox Conditions of the Soil Matrix. Environ. Sci. Technol. 2014, 48, 1549-1556. [CrossRef]

8. Armstrong, W. Radial Oxygen Losses from Intact Rice Roots as Affected by Distance from Apex, Respiration and Waterlogging. Physiol. Plant. 1971, 25, 192-197. [CrossRef]

9. Mendelssohn, I.A.; Kleiss, B.A.; Wakeley, J.S. Factors Controlling the Formation of Oxidized Root Channels-A Review. Wetlands 1995, 15, 37-46. [CrossRef]

10. Wang, Z.P.; Delaune, R.D.; Masscheleyn, P.H.; Patrick, W.H. Soil Redox and Ph Effects on Methane Production in a Flooded Rice Soil. Soil Sci. Soc. Am. J. 1993, 57, 382-385. [CrossRef]

11. Yu, T.R. Characteristics of Soil Acidity of Paddy Soils in Relation to Rice Growth. Plant-Soil Interact. Low pH 1991, 45, 107-112.

12. Liesack, W.; Schnell, S.; Revsbech, N.P. Microbiology of flooded rice paddies. Fems Microbiol. Rev. 2000, 24, 625-645. [CrossRef] [PubMed]

13. Hori, T.; Muller, A.; Igarashi, Y.; Conrad, R.; Friedrich, M.W. Identification of iron-reducing microorganisms in anoxic rice paddy soil by C-13-acetate probing. Isme J. 2010, 4, 267-278. [CrossRef] [PubMed]

14. Achtnich, C.; Bak, F.; Conrad, R. Competition for Electron-Donors among Nitrate Reducers, Ferric Iron Reducers, Sulfate Reducers, and Methanogens in Anoxic Paddy Soil. Biol. Fertil. Soils 1995, 19, 65-72. [CrossRef]

15. Druschel, G.K.; Emerson, D.; Sutka, R.; Suchecki, P.; Luther, G.W. Low-oxygen and chemical kinetic constraints on the geochemical niche of neutrophilic iron(II) oxidizing microorganisms. Geochim. Cosmochim. Acta 2008, 72, 3358-3370. [CrossRef]

16. Lueder, U.; Druschel, G.; Emerson, D.; Kappler, A.; Schmidt, C. Quantitative analysis of O-2 and Fe2+ profiles in gradient tubes for cultivation of microaerophilic Iron(II)-oxidizing bacteria. Fems Microbiol. Ecol. 2018, 94. [CrossRef]

17. Emerson, D.; Weiss, J.V.; Megonigal, J.P. Iron-oxidizing bacteria are associated with ferric hydroxide precipitates (Fe-plaque) on the roots of wetland plants. Appl. Environ. Microbiol. 1999, 65, 2758-2761. [CrossRef] 
18. Neubauer, S.C.; Toledo-Duran, G.E.; Emerson, D.; Megonigal, J.P. Returning to their roots: Iron-oxidizing bacteria enhance short-term plaque formation in the wetland-plant rhizosphere. Geomicrobiol. J. 2007, 24, 65-73. [CrossRef]

19. Maisch, M.; Lueder, U.; Kappler, A.; Schmidt, C. (a), Iron Lung: How Rice Roots Induce Iron Redox Changes in the Rhizosphere and Create Niches for Microaerophilic Fe(II)-Oxidizing Bacteria. Environ. Sci. Technol. Lett. 2019, 6, 600-605. [CrossRef]

20. Urrutia, M.M.; Roden, E.E.; Fredrickson, J.K.; Zachara, J.M. Microbial and surface chemistry controls on reduction of synthetic Fe(III) oxide minerals by the dissimilatory iron-reducing bacterium Shewanella alga. Geomicrobiol. J. 1998, 15, 269-291. [CrossRef]

21. Langley, S.; Gault, A.; Ibrahim, A.; Renaud, R.; Fortin, D.; Clark, I.D.; Ferris, F.G. A Comparison of the Rates of Fe(III) Reduction in Synthetic and Bacteriogenic Iron Oxides by Shewanella putrefaciens CN32. Geomicrobiol. J. 2009, 26, 57-70. [CrossRef]

22. Bridge, T.A.M.; Johnson, D.B. Reduction of soluble iron and reductive dissolution of ferric iron-containing minerals by moderately thermophilic iron-oxidizing bacteria. Appl. Environ. Microbiol. 1998, 64, 2181-2186. [CrossRef] [PubMed]

23. Bennett, B.; Dudas, M.J. Release of arsenic and molybdenum by reductive dissolution of iron oxides in a soil with enriched levels of native arsenic. J. Environ. Eng. Sci. 2003, 2, 265-272. [CrossRef]

24. Hansel, C.M.; Fendorf, S.; Sutton, S.; Newville, M. Characterization of Fe plaque and associated metals on the roots of mine-waste impacted aquatic plants. Environ. Sci. Technol. 2001, 35, 3863-3868. [CrossRef] [PubMed]

25. Kirk, G.J.D.; Bajita, J.B. Root-Induced Iron Oxidation, Ph Changes and Zinc Solubilization in the Rhizosphere of Lowland Rice. New Phytol. 1995, 131, 129-137. [CrossRef]

26. Wahid, P.A.; Kamalam, N.V. Reductive Dissolution of Crystalline and Amorphous Fe(Iii) Oxides by Microorganisms in Submerged Soil. Biol. Fertil. Soils 1993, 15, 144-148. [CrossRef]

27. Weber, K.A.; Achenbach, L.A.; Coates, J.D. Microorganisms pumping iron: Anaerobic microbial iron oxidation and reduction. Nat. Rev. Microbiol. 2006, 4, 752-764. [CrossRef]

28. Yu, H.Y.; Li, F.B.; Liu, C.S.; Huang, W.; Liu, T.X.; Yu, W.M. Iron Redox Cycling Coupled to Transformation and Immobilization of Heavy Metals: Implications for Paddy Rice Safety in the Red Soil of South China. Adv. Agron. 2016, 137, 279-317.

29. Weiss, J.V.; Emerson, D.; Backer, S.M.; Megonigal, J.P. Enumeration of Fe(II)-oxidizing and Fe(III)-reducing bacteria in the root zone of wetland plants: Implications for a rhizosphere iron cycle. Biogeochemistry 2003, 64,77-96. [CrossRef]

30. Garnier, J.; Garnier, J.M.; Vieira, C.L.; Akerman, A.; Chmeleff, J.; Ruiz, R.I.; Poitrasson, F. Iron isotope fingerprints of redox and biogeochemical cycling in the soil-water-rice plant system of a paddy field. Sci. Total Environ. 2017, 574, 1622-1632. [CrossRef]

31. Roden, E.E.; Wetzel, R.G. Kinetics of microbial Fe(III) oxide reduction in freshwater wetland sediments. Limnol. Oceanogr. 2002, 47, 198-211. [CrossRef]

32. Hoagland, D.R.; Arnon, D.I. The water-culture method for growing plants without soil. In Circular, 2nd ed.; California Agricultural Experiment Station: Berkeley, CA, USA, 1950; Volume 347.

33. Maisch, M.; Lueder, U.; Laufer, K.; Scholze, C.; Kappler, A.; Schmidt, C. (b), Contribution of Microaerophilic Iron(II)-Oxidizers to Iron(III) Mineral Formation. Environ. Sci. Technol. 2019, 53, 8197-8204. [CrossRef] [PubMed]

34. Kirk, G. The Biogeochemistry of Submerged Soils; John Wiley \& Sons: Chichester, UK, 2004.

35. Flessa, H.; Fischer, W.R. Plant-Induced Changes in the Redox Potentials of Rice Rhizospheres. Plant Soil 1992, 143, 55-60. [CrossRef]

36. Schmidt, H.; Eickhorst, T.; Tippkotter, R. Monitoring of root growth and redox conditions in paddy soil rhizotrons by redox electrodes and image analysis. Plant Soil 2011, 341, 221-232. [CrossRef]

37. Benjamin, J.G.; Nielsen, D.C. A method to separate plant roots from soil and analyze root surface area. Plant Soil 2004, 267, 225-234. [CrossRef]

38. Muehe, E.M.; Scheer, L.; Daus, B.; Kappler, A. Fate of Arsenic during Microbial Reduction of Biogenic versus Abiogenic As-Fe(III)-Mineral Coprecipitates. Environ. Sci. Technol. 2013, 47, 8297-8307. [CrossRef]

39. Muehe, E.M.; Obst, M.; Hitchcock, A.; Tyliszczak, T.; Behrens, S.; Schröder, C.; Byrne, M.J.; Michel, F.M.; Krämer, U.; Kappler, A. Fate of Cd during Microbial Fe(III) Mineral Reduction by a Novel and Cd-Tolerant Geobacter Species. Environ. Sci. Technol. 2013, 47, 14099-14109. [CrossRef] 
40. Stookey, L.L. Ferrozine-A New Spectrophotometric Reagent for Iron. Anal. Chem. 1970, 42, 779-781. [CrossRef]

41. Seyfferth, A.L.; Webb, S.M.; Andrews, J.C.; Fendorf, S. Arsenic Localization, Speciation, and Co-Occurrence with Iron on Rice (Oryza sativa L.) Roots Having Variable Fe Coatings. Environ. Sci. Technol. 2010, 44, 8108-8113. [CrossRef]

42. Blute, N.K.; Brabander, D.J.; Hemond, H.F.; Sutton, S.R.; Newville, M.G.; Rivers, M.L. Arsenic sequestration by ferric iron plaque on cattail roots. Environ. Sci. Technol. 2004, 38, 6074-6077. [CrossRef]

43. Hiemstra, T.; van Riemsdijk, W.H. A surface structural model for ferrihydrite I: Sites related to primary charge, molar mass, and mass density. Geochim. Cosmochim. Acta 2009, 73, 4423-4436. [CrossRef]

44. Matsumoto, S.; Kasuga, J.; Makino, T.; Arao, T. Evaluation of the effects of application of iron materials on the accumulation and speciation of arsenic in rice grain grown on uncontaminated soil with relatively high levels of arsenic. Environ. Exp. Bot. 2016, 125, 42-51. [CrossRef]

45. Tan, X.Z.; Shao, D.G.; Liu, H.H.; Yang, F.S.; Xiao, C.; Yang, H.D. Effects of alternate wetting and drying irrigation on percolation and nitrogen leaching in paddy fields. Paddy Water Environ. 2013, 11, 381-395. [CrossRef]

46. Carlson, J.J.; Kawatra, S.K. Factors Affecting Zeta Potential of Iron Oxides. Miner. Process. Extr. Metall. Rev. 2013, 34, 269-303. [CrossRef]

47. Aimrun, W.; Amin, M.S.M.; Eltaib, S.M. Effective porosity of paddy soils as an estimation of its saturated hydraulic conductivity. Geoderma 2004, 121, 197-203. [CrossRef]

48. Stumm, W.; Wehrli, B.; Wieland, E. Surface Complexation and Its Impact on Geochemical Kinetics. Croat. Chem. Acta 1987, 60, 429-456.

49. Gu, B.H.; Schmitt, J.; Chen, Z.; Liang, L.Y.; Mccarthy, J.F. Adsorption and Desorption of Different Organic-Matter Fractions on Iron-Oxide. Geochim. Cosmochim. Acta 1995, 59, 219-229. [CrossRef]

50. Howeler, R.H.; Bouldin, D.R. The Diffusion and Consumption of Oxygen in Submerged Soils1. Soil Sci. Soc. Am. J. 1971, 35, 202-208. [CrossRef]

51. Kirby, C.S.; Thomas, H.M.; Southam, G.; Donald, R. Relative contributions of abiotic and biological factors in Fe(II) oxidation in mine drainage. Appl. Geochem. 1999, 14, 511-530. [CrossRef]

52. Cahyani, V.R.; Murase, J.; Ikeda, A.; Taki, K.; Asakawa, S.; Kimura, M. Bacterial communities in iron mottles in the plow pan layer in a Japanese rice field: Estimation using PCR-DGGE and sequencing analyses. Soil Sci. Plant Nutr. 2008, 54, 711-717. [CrossRef]

53. Emerson, D.; Moyer, C.L. Neutrophilic Fe-Oxidizing bacteria are abundant at the Loihi Seamount hydrothermal vents and play a major role in Fe oxide deposition. Appl. Environ. Microbiol. 2002, 68, 3085-3093. [CrossRef] [PubMed]

54. Chan, C.S.; Emerson, D.; Luther, G.W. The role of microaerophilic Fe-oxidizing micro-organisms in producing banded iron formations. Geobiology 2016, 14, 509-528. [CrossRef] [PubMed]

55. Melton, E.D.; Swanner, E.D.; Behrens, S.; Schmidt, C.; Kappler, A. The interplay of microbially mediated and abiotic reactions in the biogeochemical Fe cycle. Nat. Rev. Microbiol. 2014, 12, 797-808. [CrossRef] [PubMed]

56. King, G.M.; Garey, M.A. Ferric Iron Reduction by Bacteria Associated with the Roots of Freshwater and Marine Macrophytes. Appl. Environ. Microbiol. 1999, 65, 4393. [CrossRef]

57. Weiss, J.V.; Emerson, D.; Megonigal, J.P. Geochemical control of microbial Fe(III) reduction potential in wetlands: Comparison of the rhizosphere to non-rhizosphere soil. Fems Microbiol. Ecol. 2004, 48, 89-100. [CrossRef]

58. Colombo, C.; Palumbo, G.; He, J.Z.; Pinton, R.; Cesco, S. Review on iron availability in soil: Interaction of Fe minerals, plants, and microbes. J. Soils Sediments 2014, 14, 538-548. [CrossRef]

59. Dannenberg, S.; Conrad, R. Effect of rice plants on methane production and rhizospheric metabolism in paddy soil. Biogeochemistry 1999, 45, 53-71. [CrossRef]

60. Strom, L.; Mastepanov, M.; Christensen, T.R. Species-specific effects of vascular plants on carbon turnover and methane emissions from wetlands. Biogeochemistry 2005, 75, 65-82. [CrossRef]

61. Lovley, D.R.; Giovannoni, S.J.; White, D.C.; Champine, J.E.; Phillips, E.J.P.; Gorby, Y.A.; Goodwin, S. Geobacter-Metallireducens Gen-Nov Sp-Nov, a Microorganism Capable of Coupling the Complete Oxidation of Organic-Compounds to the Reduction of Iron and Other Metals. Arch. Microbiol. 1993, 159, 336-344. [CrossRef]

62. Cornell, R.M.; Schneider, W.; Giovanoli, R. The Transformation of Ferrihydrite into Lepidocrocite. Clay Miner. 1989, 24, 549-553. [CrossRef] 
63. Jacob, D.L.; Otte, M.L. Conflicting processes in the wetland plant rhizosphere: Metal retention or mobilization? Water Air Soil Pollut. Focus 2003, 3, 91-104. [CrossRef]

64. Xu, X.; Mills, G.L. Do constructed wetlands remove metals or increase metal bioavailability? J. Environ. Manag. 2018, 218, 245-255. [CrossRef]

65. Elsner, M.; Schwarzenbach, R.P.; Haderlein, S.B. Reactivity of Fe(II)-bearing minerals toward reductive transformation of organic contaminants. Environ. Sci. Technol. 2004, 38, 799-807. [CrossRef] [PubMed]

66. Bonneville, S.; van Cappellen, P.; Behrends, T. Microbial reduction of iron(III) oxyhydroxides: Effects of mineral solubility and availability. Chem. Geol. 2004, 212, 255-268. [CrossRef]

67. Munch, J.C.; Ottow, J.C.G. Preferential Reduction of Amorphous to Crystalline Iron-Oxides by Bacterial-Activity. Soil Sci. 1980, 129, 15-21. [CrossRef]

68. Roden, E.E.; Zachara, J.M. Microbial reduction of crystalline iron(III) oxides: Influence of oxide surface area and potential for cell growth. Environ. Sci. Technol. 1996, 30, 1618-1628. [CrossRef]

69. Najem, T.; Langley, S.; Fortin, D. A comparison of Fe(III) reduction rates between fresh and aged biogenic iron oxides (BIOS) by Shewanella putrefaciens CN32. Chem. Geol. 2016, 439, 1-12. [CrossRef]

70. Kludze, H.K.; Delaune, R.D.; Patrick, W.H. Aerenchyma Formation and Methane and Oxygen-Exchange in Rice. Soil Sci. Soc. Am. J. 1993, 57, 386-391. [CrossRef]

71. Colmer, T.D.; Cox, M.C.H.; Voesenek, L.A.C.J. Root aeration in rice (Oryza sativa): Evaluation of oxygen, carbon dioxide, and ethylene as possible regulators of root acclimatizations. New Phytol. 2006, 170, 767-777. [CrossRef]

72. Lovley, D.R.; Ueki, T.; Zhang, T.; Malvankar, N.S.; Shrestha, P.M.; Flanagan, K.A.; Aklujkar, M.; Butler, J.E.; Giloteaux, L.; Rotaru, A.E.; et al. Geobacter: The Microbe Electric's Physiology, Ecology, and Practical Applications. Adv. Microb. Physiol. 2011, 59, 1-100.

73. Colmer, T.D. Aerenchyma and an inducible barrier to radial oxygen loss facilitate root aeration in upland, paddy and deep-water rice (Oryza sativa L.). Ann. Bot. 2003, 91, 301-309. [CrossRef] [PubMed]

74. Jackel, U.; Schnell, S. Suppression of methane emission from rice paddies by ferric iron fertilization. Soil Biol. Biochem. 2000, 32, 1811-1814. [CrossRef]

75. Furukawa, Y.; Inubushi, K. Effect of application of iron materials on methane and nitrous oxide emissions from two types of paddy soils. Soil Sci. Plant Nutr. 2004, 50, 917-924. [CrossRef]

76. Cai, A.D.; Feng, W.T.; Zhang, W.J.; Xu, M.G. Climate, soil texture, and soil types affect the contributions of fine-fraction-stabilized carbon to total soil organic carbon in different land uses across China. J. Environ. Manag. 2016, 172, 2-9. [CrossRef] [PubMed] 